\title{
Private or Public Equity? The Evolving Entrepreneurial Finance Landscape * +
}

\author{
Michael Ewens \\ California Institute of Technology
}

\author{
Joan Farre-Mensa \\ University of Illinois at Chicago
}

February 2, 2022

\footnotetext{
* This article has been prepared for the Annual Review of Financial Economics. The companion website for the paper (with data sources and future updates) can be found at https://privatepublicmkts.com. We thank an anonymous reviewer, Jun Chen, Bill Janeway, Josh Lerner, Ramana Nanda, Gabriel Rauterberg, and Emmanuel Yimfor for comments. We also thank Minmo Gahng, Oleg Gredil, and Jay Ritter for generously sharing data. Kexin Feng provided excellent research assistance.

${ }^{\dagger}$ Address for correspondence: California Institute of Technology D.H.S.S. (MC 228-77), 1200 East California Blvd., Pasadena, CA 91125; e-mail: mewens@caltech.edu (Ewens). 2122 University Hall, University of Illinois at Chicago, 601 S. Morgan Street, Chicago, IL 60607; e-mail: jfarre@uic.edu (Farre-Mensa).
} 


\title{
Private or Public Equity? The Evolving Entrepreneurial Finance Landscape
}

\begin{abstract}
The U.S. entrepreneurial finance market has changed dramatically over the last two decades. Entrepreneurs raising their first round of venture capital retain 30\% more equity in their firm and are more likely to control their board of directors. Late-stage startups are raising larger amounts of capital in the private markets from a growing pool of traditional and new investors. These private market changes have coincided with a sharp decline in the number of firms going public_ — and when firms do go public, they are older and have raised more private capital. To understand these facts, we provide a systematic description of the differences between private and public firms. Next, we review several regulatory, technological, and competitive changes affecting both startups and investors that help explain how the trade-offs between going public and staying private have changed. We conclude by listing several open research questions.
\end{abstract}

Key words: entrepreneurial finance, private equity, private firm, IPOs, venture capital, financial intermediation.

JEL classification: G23, G24, G28, G34, G38. 


\section{Introduction}

This article describes the changes undergone by the U.S. entrepreneurial finance market over the last two decades and provides a framework to analyze the causes and consequences of these changes. These changes have impacted both early-stage and late-stage startups, and they are the result of shifts in both the supply and demand for private and public equity capital.

At the early-stage level, technological innovations such as cloud computing in 2006 have decreased startups' financing needs, particularly during the initial, experimental stage of the entrepreneurial process. At the same time, the emergence of incubators and of new online platforms that help connect investors to startups - alongside the regulatory changes that have facilitated them - have contributed to a marked increase in the fundraising options available to early-stage startups. We show that a key consequence of these changes is that entrepreneurs are increasingly able to retain control of their board and a higher equity stake after raising their initial financing rounds.

As these entrepreneurs' startups mature, they gain access to a late-stage private equity market that has grown five-fold: In 2002, the aggregate amount of private equity capital invested in venture capital (VC)-backed startups raising a Series C or higher round was $\$ 14.2$ billion; in 2019 , it was $\$ 80$ billion. Much of this late-stage capital is now supplied by non-traditional startup investors such as private equity (PE) funds, mutual funds, and hedge funds. ${ }^{1}$ This abundant supply of late-stage private capital means that many late-stage startups have little need to go public to finance their growth. As a result, firms are now less likely to go public and when they do go public, they are older and have raised more private capital than in the 1990s. In fact, we show that the number of startups raising over $\$ 99$ million in a single financing round, a sum historically only available via the public markets, grew 31-fold from 2002 to 2019.

What explains the increase in the supply of late-stage private capital? First, regulatory changes such as the National Securities Markets Improvement Act (NSMIA) of 1996 have made it easier for $\mathrm{VC}$ and $\mathrm{PE}$ funds to raise large funds. In addition, these funds have benefited from a

\footnotetext{
${ }^{1}$ Throughout this article, "PE funds" are funds traditionally focused on leveraged buyouts, and increasingly also on growth-equity investments (see Section 3.2.2); they do not include VC funds.
} 
sharp increase in allocations to private equity by institutional investors such as public pension funds and higher-education endowments - in the case of pension funds, perhaps in an attempt to close their ballooning funding gaps. Third, the entry into the private equity market of mutual funds and hedge funds - traditional investors in public equity - has likely been spurred by the increased competition they face from passively managed index funds: Investing in private firms can help active funds beat the returns of their passive counterparts, thereby justifying the active funds' higher fees.

Of course, the fact that successful startups can continue financing their growth while remaining private does not mean that they have to remain private. We argue that, in addition to the increased supply of late-stage private capital, two demand-side changes help explain why many startups choose to remain private longer. First, founders' increased control of their firms after raising their initial financing rounds means that they enjoy greater bargaining power vis-àvis investors at the time of making exit decisions. Founders can use this bargaining power to fulfill their desire to maintain control of their firms by delaying their exit. Second, the secular growth in the importance of R\&D investments and intangible assets means that firms face greater disclosure costs. As a result, the benefits of staying private and thus avoiding the disclosure regulations that apply to public firms have increased.

The article proceeds as follows. Section 2 begins by describing the differences between public and private firms. Section 3 describes the changes in the entrepreneurial finance market over the last two decades, using Section 2 as a framework to understand these changes. Section 4 concludes by listing several open research questions.

\section{How do public and private firms differ?}

This section defines public and private firms, describes the differences between them, and discusses how these differences impact a firm's listing decision. Our focus throughout this section is on the current regulatory environment surrounding public and private firms; Section 3 will discuss how these regulations have evolved over the last two decades. 


\subsection{Defining public, private, and "semi-public" firms}

The finance literature agrees on the definition of publicly listed (henceforth, "public") firms: those whose shares are listed on a national securities exchange (e.g., the NYSE and Nasdaq in the U.S.). It is less clear how to define privately held (henceforth, "private") firms. The most expansive definition - all firms that are not public are private - includes two (overlapping) groups of non-public firms facing distinct liquidity, regulatory, and disclosure environments.

The first group are firms whose shares are listed on over-the-counter (OTC) markets. ${ }^{2}$ The second group are firms without listed shares that must nonetheless regularly file their financial statements with the SEC because of one of three reasons: (a) their debt is listed on an exchange, (b) they have over $\$ 10$ million in assets and their shares are held of record by at least 2,000 persons or 500 non-accredited investors, or (c) they have registered equity or debt securities with the SEC during the current year or, if in a prior year, these securities are currently held by at least 300 record holders. ${ }^{3}$

In this review, our definitions of private firms and private capital markets focus on "pure" private firms and do not include the prior two groups of firms - which we will call "semi-public" firms for short. While this focus is not overly restrictive (most non-public firms and most firms that go public are pure private firms), we note that some of the differences between public and private firms described below do not apply to semi-public firms.

\subsection{Private and public firm regulation}

\subsubsection{Initial listing of shares in an exchange}

A company can go public - - i.e., list its shares on a national exchange - in three ways. The traditional way has been to conduct an initial public offering (IPO) of its common stock. More recently, two alternative approaches have emerged that allow private firms to avoid some costs (while giving up some benefits) associated with traditional IPOs: a direct listing, whereby a private firm lists its shares on a national exchange without using an underwriter, and a Special

\footnotetext{
${ }^{2}$ Brüggemann et al. (2018) note that OTC markets offer a variety of trading environments with different regulatory and disclosure regimes, comprising venue rules and state laws beyond SEC regulation.

${ }^{3}$ Holder thresholds are different for banks (Morrison \& Foerster 2018).
} 
Purpose Acquisition Company (SPAC) merger, whereby a private firm becomes public by merging with a public SPAC.

Before a company's shares can be offered for sale to the public and listed on a national exchange, the company must register them with the SEC, usually by filing Form S-1. ${ }^{4}$ The form includes descriptions of the company's business operations, risk factors, and management as well as audited financial statements. Once the SEC declares its registration statement effective, the firm is subject to the reporting requirements of the 1934 Exchange Act, including the filing of annual reports on Form 10-K, quarterly reports on Form 10-Q, and current reports disclosing certain material transactions on Form 8-K. ${ }^{5}$ These reporting obligations continue for as long as the firms' shares are listed on a national exchange (and potentially beyond, as discussed in Section 2.1). ${ }^{6}$ In addition, public firms (and SEC reporting semi-public firms) need to comply with Regulation Fair Disclosure (Reg FD), which aims to guarantee a level playing field among investors by prohibiting the selective disclosure of material non-public information.

Going public also triggers several non-disclosure regulations at the federal, state, and exchange levels. At the federal level, some governance regulations - most notably, those in the Sarbanes-Oxley Act, discussed in Section 3.1 - apply only to public (and SEC reporting semipublic) firms. Similarly, some states impose governance regulations that apply only to public firms, such as California's board diversity requirements (SB 826 and AB 979). Conversely, public firms are largely exempt from state blue sky laws when issuing securities; by contrast, private firms may or may not be exempt from them (see Section 2.2.3).

\footnotetext{
${ }^{4}$ Registration and listing are distinct events. Registration is required for listing, but a firm may choose to register its equity (or debt) securities to increase the pool of investors that can hold them without listing them. Registration is a security-specific event: Some of the shares of a public firm may be unregistered and so they are ineligible for listing.

${ }^{5}$ When a private firm goes public via a SPAC merger, it avoids having to file a Form S-1, but it still becomes subject to the Exchange Act's reporting requirements.

${ }^{6}$ Small or young public firms (those that meet the requirements to be considered smaller reporting companies, nonaccelerated filers, or emerging growth companies) are subject to scaled back disclosures (e.g., Ewens et al. 2021).
} 
Finally, to list its shares on a national exchange, a firm is required to comply with the exchange's listing standards. These include size and stock liquidity requirements, disclosure and corporate governance rules, and listing fees. ${ }^{7}$

\subsubsection{Follow-on equity offerings by public firms}

Once a firm is public, it can raise additional capital via a follow-on offering, whereby the company registers additional shares and offers them to the public, traditionally via a seasoned equity offering (SEO). ${ }^{8}$ The mechanics of price formation and share allocation differ depending on the type of follow-on offering chosen (Johnson et al. 2020). As in an IPO, the shares sold in a follow-on offering can be primary (if the shares are sold by the firm itself) or secondary (if the shares are sold by certain shareholders).

To register the shares sold in a follow-on offering, public firms must file Form S-1 or its abbreviated version, Form S-3. A public firm can also use these forms to file a shelf registration statement to register securities that it will sell in the future, when the firm needs capital or market conditions are favorable. ${ }^{9}$

\subsubsection{Raising equity as a private firm}

The ability of public firms to sell their shares without restrictions to the public as well as investors' ability to then easily trade those shares in an exchange contrasts with the limitations faced by private firms and their investors. Indeed, to sell unregistered shares to investors, private firms need to rely on an exemption from registration. Depending on the exemption, firms are limited in the amount of capital they can raise, the number of investors who can buy shares, or the characteristics of these investors.

Two popular exemptions are Rules 506(b) and 506(c) of Regulation D, which allow private firms to raise an unlimited amount of capital from an unlimited number of investors as long as they are accredited-i.e., if they are institutions, individuals or couples with a net worth (not

\footnotetext{
${ }^{7}$ See NYSE (2021) and Nasdaq (2021).

${ }^{8}$ Public firms also have the option to sell unregistered shares to accredited investors via a private investment in public equity (PIPE).

${ }^{9}$ See Harmetz \& Berman (2017) for further details.
} 
including their primary residence) over $\$ 1$ million, or individuals (couples) with income exceeding \$200,000 (\$300,000). ${ }^{10}$ In addition, when selling shares under Rule 506(b), up to 35 non-accredited investors can also participate in the offering. By contrast, when relying on Rule 506(c), all investors must be accredited and issuers must take "reasonable steps" to verify this; in exchange, issuers are allowed to solicit and advertise the offering, which they cannot do under Rule 506(b). A key advantage of Rules 506(b) and 506(c) is that the issuer is exempt from complying with state blue sky (i.e., securities) laws (Ewens \& Farre-Mensa 2020). ${ }^{11}$

Investors in a private firm's Rule 506(b) or 506(c) offering receive "restricted securities" that are not freely tradable: they typically need to hold the securities for one year before they can resell them to the public under Rule $144 .{ }^{12}$ But even after one year, reselling often requires the private issuer's consent (SEC 2013) and can be labor intensive, as the seller needs to find a willing buyer without relying on an exchange.

While investors in private firms can invest directly, as with angel investors (Shane 2008, Kerr et al. 2014), they often rely on intermediaries such as VC or PE funds. These funds raise capital from limited partners (LPs): institutions (e.g., pension funds and university endowments) and other accredited investors. The fund managers (general partners (GPs)) then select private firms in which to invest this capital. In contrast to mutual funds and most investors in public firms, $\mathrm{VC}$ and PE investors tend to be closely involved in advising and monitoring their portfolio companies (Da Rin et al. 2013). This active involvement is facilitated by the common use of (convertible) preferred stock in private financings, which provides investors with a complex set of cash flow, information, and control rights (Metrick \& Yasuda 2021).

\subsection{How do the financing and informational frictions faced by public and private firms differ?}

We now discuss how the regulatory differences between public and private firms affect the financing and information environments surrounding them.

\footnotetext{
${ }^{10}$ See Dodhia (2020) for other less common qualification criteria.

${ }^{11}$ Other exemptions from registration that do place limits on the size of the offering and do not exempt issuers from state blue sky laws are Rule 504, Regulation A - Tier 1, and Regulation Crowdfunding (SEC 2021).

${ }^{12}$ Alternatively, investors can opt for a private resale of the restricted securities by relying on the so-called Section 4(a)(1 1/2) exemption (largely codified in 2015 as Section 4(a)(7)), a complex and time-consuming process (Effron 2016, Sweet 2016).
} 


\subsubsection{Differences in stock liquidity and cost of capital}

By registering and listing their shares, public firms increase the shares' liquidity and gain access to a larger pool of well-diversified investors, which standard asset pricing models predict should translate into a lower cost of equity, all else equal (Longstaff 1995, Brennan \& Torous 1999, Heaton \& Lucas 2004).

To quantify the difference in the cost of equity between public and private firms, one would ideally compare the costs of two identical firms that differ only in their listing status. Such a comparison is not possible because firms choose whether to be public or private after considering the relative costs and benefits of each option - a recurring challenge in the literature comparing public and private firms. Another challenge is that the premium paid by private firms when raising equity is unlikely to be unique: Abudy et al.'s (2016) model predicts that the private premium increases with a firm's asset risk and leverage ratio, while it is negatively related to taxes and owner diversification.

These challenges notwithstanding, several papers have attempted to quantify private firms' valuation discount. Officer's (2007) analysis of acquisition equity multiples shows that private targets sell at an average discount of $15 \%$ to $30 \%$ relative to industry- and size-matched public targets. Koeplin et al. (2000) find similar results.

Public firms also appear to benefit from a lower cost of debt. Saunders \& Steffen (2011) find that U.K. private firms pay loan spreads that are between 26 and 60 basis points higher than matched public firms. ${ }^{13}$ They emphasize lenders' higher costs of information production when lending to private firms, private firms' lower bargaining power, and their higher ownership concentration as key channels driving private firms' higher borrowing costs. Kovner \& Wei (2014) and Badertscher et al. (2019) reach similar conclusions when comparing the costs faced by public and SEC-reporting semi-public firms in the U.S. public bond market.

Public firms' higher stock liquidity not only enables them to raise capital at a lower cost, but it also provides currency for stock-financed acquisitions (Celikyurt et al. 2010). In addition, by

\footnotetext{
${ }^{13}$ In the U.K., all public and private firms are required to publicly file their financial statements. This facilitates research on U.K. private firms, but it means that their disclosure regulations are closer to those faced by SEC reporting semi-public firms than pure private firms in the U.S.
} 
registering their shares and listing them on a major exchange, public firms make it easier for their founders, early investors, and stock-compensated employees to sell their shares. This liquidity is valuable to $\mathrm{VC}$ investors, who typically need to exit their investments before the end of their fund's life-cycle and for whom IPOs bring large reputational benefits (Gompers 1996).

\subsubsection{Differences in the information environment}

The information environment faced by public (and SEC reporting semi-public) firms is markedly different from that faced by private firms. Public firms - but not private ones - are required to make their financial statements publicly available and thus accessible to any potential investor. In addition, Reg FD does not allow public firms to disclose material information to selected investors, ensuring that all investors have access to the same raw information about all public firms.

The requirement that all potential investors in a public firm have access to the same information means that their managers face a two-audiences problem when raising capital: they need to trade off the benefits of information disclosure with the costs of making the information public and thus available to their competitors (Bhattacharya \& Ritter 1983). By contrast, (pure) private firms do not face this trade-off because they are not restricted in their ability to disclose information to selected investors - an advantage that is particularly important in industries where proprietary information is most valuable (Maksimovic \& Pichler 2001, Farre-Mensa 2017).

To illustrate, Google's (2004) management wrote in a letter to prospective investors in the firm's S-1 filing: “As a smaller private company, Google kept business information closely held, and we believe this helped us against competitors" (p. iv). The letter continued: "As a public company, we will of course provide you with all information required by law... But we will not unnecessarily disclose all of our strengths, strategies and intentions." By contrast, VCs and other private investors often have almost unfettered access to their portfolio companies (e.g., Bernstein et al. 2016). Google's example thus points to a complex relationship between a firm's listing status and the information available to investors: While there is far more publicly available information about the average public than the average private firm, private firms' shareholders often gain access to proprietary information that is off-limits to investors in public firms. 
The information environment surrounding public and private firms differs in one additional aspect: public firms' stock prices aggregate the information available to a variety of market participants and are available in real time. As a result, stock prices can help public managers make better investment and acquisition decisions (Dow \& Gorton 1997, Hsieh et al. 2011). But prices can also be a distraction and lead to suboptimal decision making, particularly if markets are inefficient (Baker \& Wurgler 2013, section 2.4) or in the presence of agency conflictsdiscussed next.

\subsubsection{Differences in agency problems}

Public firms' ability to gain access to a large pool of well-diversified investors and the associated risk-sharing benefits come at the expense of separating ownership and control, opening the door to agency problems (Jensen \& Meckling 1976). The potential for agency problems is exacerbated in situations where public managers' two-audiences problem prevents them from sharing proprietary information with shareholders, leading to increased information asymmetry.

One type of agency problem that has received considerable attention when comparing public and private firms has been short-termism (Asker et al. 2015). Stein's (1989) model shows that a manager whose utility depends on both the firm's long-term earnings and its current stock price may sacrifice long-term value to boost the firm's stock price even if investors anticipate this behavior. The reason is that investors expect the firm's current earnings to be inflated by borrowing from the future and discount them accordingly — and the manager has no way to credibly commit not to engage in this inefficient behavior. A key model assumption is that investors cannot observe the amount of borrowing from the future, thus highlighting the role of information asymmetry in public firms' agency problems.

Agency problems can also arise in private firms, particularly in environments with weak property rights where majority shareholders can exploit minority shareholders (La Porta et al. 1999, Loderer \& Waelchli 2010). At the same time, Holmström \& Tirole (1993) argue that liquid stock prices can help monitor public managers' performance. More generally, the vast corporate governance literature outlines a variety of mechanisms that firms can use to alleviate agency problems (see Shleifer \& Vishny (1997), Stein (2003), and Hermalin \& Weisbach (2017) for reviews). Thus, while public firms' separation of ownership and control increases the potential 
for agency problems, the extent to which agency problems distort the behavior of public firms relative to private ones remains an open empirical question.

\subsubsection{Differences in equity issuance expenses}

The expenses associated with raising equity via the public and private markets can be substantially different — although the latter are hard to quantify. On the public side, IPO expenses include underwriting fees, IPO underpricing, and (comparatively smaller) exchange listing fees and miscellaneous expenses. For moderate-size IPOs, underwriting fees are almost always 7\% of gross IPO proceeds, but they can be lower for larger IPOs (Ritter 2011). In addition, IPO firms leave considerable money on the table due to underpricing: first-day IPO returns averaged 17\% from 2001 through 2020 (Ritter 2021, Table 1). SEO expenses tend to be lower than for IPOs: from 2008 through 2015, the mean underwriting fee equaled 4.5\% of SEO gross proceeds (Billett et al. 2019, Table 3), while the mean SEO announcement return from 1996 through 2012 was $-2 \%$ (Akhigbe \& Whyte 2015, Table 4).

We are not aware of any study of private firms' equity issuance expenses. However, to the extent that such firms often raise equity via $\mathrm{VC}$ and $\mathrm{PE}$ funds, it is worth noting that the fees charged by these funds (and ultimately borne by their portfolio companies) can be orders of magnitude higher than those charged by mutual funds investing in public firms (Robinson \& Sensoy 2013, Phalippou et al. 2018). ${ }^{14}$

\subsection{The listing decision}

Do the above differences in the financing and information frictions faced by public and private firms affect listing decisions? A number of papers find that they do-although the precise weights that firms put on each factor, and how these weights vary across firms and over time, remain open research questions. But before reviewing these studies, it is worth delimiting our discussion's scope. First, exchange size requirements and the fixed costs associated with going public mean that most private firms are too small to consider going public. Second, while our focus is on the going public decision, the same basic trade-offs influence the decision to go

\footnotetext{
${ }^{14} \mathrm{VC}$ and PE fund managers typically charge an annual management fee (around $2 \%$ of the fund's assets) and a performance or carried interest fee (around $20 \%$ of fund profits).
} 
private (e.g., via a PE-sponsored leveraged buyout). Finally, the literature on the going public decision is vast and we do not aim to review it all here; see Lowry et al. (2017) for a recent review of the IPO literature.

Consistent with the notion that going public gives firms access to a large pool of low-cost equity capital, the need to finance investments - particularly hard to collateralize R\&D projects - appears to be a major driver of IPOs: Kim \& Weisbach (2008) show that R\&D and capital expenditures increase by 78.0 cents and 19.9 cents, respectively, per IPO dollar raised in the four years following the IPO. When IPOs involve mature firms like those studied by Pagano et al. (1998), which are not the norm in the U.S., ${ }^{15}$ capital structure adjustments rather than investments constitute the main use of IPO funds.

Consistent with listing allowing shareholders to better diversify idiosyncratic risk, Chemmanur et al. (2010) show that larger firms are more likely to go public. Relatedly, Chod \& Lyandres (2011) find that in industries with higher competition and demand uncertainty there are more public firms, which they argue suggests that public firm owners' greater diversification allows them to adopt riskier and more aggressive strategies. Furthermore, Bodnaruk et al. (2008) show that private firms owned by less diversified controlling shareholders are more likely to go public, and that these undiversified shareholders tend to sell more shares at the IPO. These findings support the idea that stock liquidity is an important consideration for many firms going public - even those with no need to raise capital for investment.

There is also support for the notion that private firms' ability to avoid public disclosures is an important factor in their decision to stay private: Aghamolla \& Thakor (2021) show that following a legal reform requiring firms to publicly disclose clinical trial information regardless of listing status, the affected firms increased their propensity to go public. As for agency considerations, Brau \& Fawcett's (2006) survey shows that managers' desire to maintain decision-making control and avoid ownership dilution - which tends to further separate ownership and control - are the two top reasons why firms stay private. One additional factor has

\footnotetext{
15 The median age in the sample of Italian IPOs analyzed by Pagano et al. (1998) is 26 years. By contrast, the median IPO firm in the U.S. is 8 years old (Ritter 2021, Table 4).
} 
been shown to influence IPO decisions: private owners' desire to go public when public investor sentiment and valuations are high (Lowry 2003).

\section{How has the entrepreneurial finance market changed over the last two decades?}

This section describes how the public and private capital markets have changed over the last two decades, using the differences between public and private firms described in Section 2 as a framework to understand the causes and consequences of these changes. To streamline our discussion, we zero in on changes in the financing choices faced by high-growth, innovative startups - the kind of firms most likely to raise venture capital (Puri \& Zarutskie 2012). As a result, our focus is on equity financings.

\subsection{Changes to public firm regulations}

The number of annual IPOs in the U.S. averaged 436 from 1991 through 2000, peaking at 677 in 1996. By contrast, from 2001 through 2020, annual IPO counts averaged 113, with a peak of 206 in 2014 (Ritter 2021, Table 1). While regulatory changes in the public equity markets are unlikely to be a major driver of this decline (Gao et al. 2013; Doidge et al. 2013, 2017), it is still helpful to review these changes.

Since the early days of the Sarbanes-Oxley Act (SOX) of 2002, there were concerns that the compliance costs of some of its provisions may be unexpectedly high, particularly for small and young public firms (SEC 2009) — the kind of firms most likely to be on the margin between being public or private. ${ }^{16}$ Since 2007 , several regulatory changes have shielded certain public firms from some of the costliest provisions of SOX, such as those related to the assessment of the effectiveness of internal control over financial reporting in Section 404. In particular, the 2012 JOBS Act created a new category of SEC reporting companies called "emerging growth companies," which benefit from scaled back disclosure requirements and are exempt from Section 404(b) of SOX.

Prior to the JOBS Act, the SEC had already provided small public firms with some reprieve in the speed and detail of their financial reporting. In particular, the SEC introduced the

\footnotetext{
${ }^{16}$ Coates \& Srinivasan (2014) review the literature on SOX and its consequences.
} 
"accelerated filer" and "large accelerated filer" reporting categories in 2002 and 2005, respectively, adding "smaller reporting company" in 2008. Taken together, these changes help explain why public firms' regulatory compliance costs, which increased markedly after SOX, returned to their pre-SOX levels in 2018 (Ewens et al. 2021).

In parallel, the SEC has also sought to make it easier for public firms to conduct follow-on offerings. Some of these changes target large firms, such as the introduction of the "well-known seasoned issuer" category in 2005. But others apply to small issuers, most notably the 2008 rule allowing firms with public floats below $\$ 75$ million to raise equity via shelf registrations, which led to a $49 \%$ increase in the treated firms' annual probability of raising equity (Gustafson \& Iliev 2017). Since 2008, the SEC also makes it easier for public companies to conduct at-the-market (ATM) follow-on offerings, direct share issuances sold in the secondary market that differ from traditional SEOs in that they forgo underwriters (Billett et al. 2019).

The last few years have also seen substantial innovation in the listing process itself. Since 2020, there has been a proliferation of firms going public via SPAC mergers. However, once all costs are considered, there is no evidence that SPACs result in lower listing expenses - if anything, the opposite appears to be the case (Gahng et al. 2021). Direct listings have higher potential to result in lower expenses, but they are too recent to draw any firm conclusionsparticularly those involving primary shares, only allowed in the NYSE since December 2020 and in the Nasdaq since March 2021.

\subsection{Changes in the private equity market}

\subsubsection{Regulatory changes}

Several important regulatory changes have impacted the private equity market over the last two decades. For completeness, we begin our review a bit further back with the 1996 NSMIA. As discussed by Ewens \& Farre-Mensa (2020), two provisions of NSMIA make it easier for private startups to raise capital, particularly late-stage rounds. First, NSMIA facilitates startups' access to out-of-state private capital by exempting certain private issuers - most notably, those relying on Rules 506(b) or 506(c) - from complying with the blue sky (i.e., securities) laws in the various states where their investors reside. Second, NSMIA makes it possible for VC and PE 
funds to raise larger funds without having to register as public investment companies (and thus be regulated like mutual funds).

VC and PE funds' ability to raise large funds was also facilitated by a provision in the Pension Protection Act of 2006 that made it easier for them to raise capital from public (i.e., governmental) pension plans without triggering certain costly fiduciary rules (Lawson 2006). The Department of Labor's decision in June 2020 to allow 401(k) and other private defined contribution pension plans to offer funds "with a private equity component" could help further increase the supply of capital available to VC and PE funds (Campagna 2020).

By contrast, two provisions of the Dodd-Frank Act of 2010 may have decreased the supply of private capital. Lindsey \& Stein (2020) show that Dodd-Frank's requirement that the value of the primary residence be excluded from net worth when determining accredited investor status decreased the amount of angel financing available to early-stage startups. Chen \& Ewens (2021) find that the Volcker Rule's restriction on VC investments by banks lowered the capital available to both VCs and startups; the restriction was reversed in 2020.

The next major legislative change affecting the private equity market was the 2012 JOBS Act. The Act makes it easier for private firms to raise capital without becoming an SEC reporting semi-public firm by increasing the threshold that triggers registration of securities from 500 to 2,000 record holders. ${ }^{17}$ In addition, the Act introduced a new registration exemption, Rule 506(c), which for the first time allows private issuers to generally solicit and advertise their offerings as long as all investors are accredited. That said, the Rule 506(b) exemption remains by far the most popular exemption (Bauguess et al. 2018).

The JOBS Act also established crowdfunding provisions, codified by the SEC in Regulation Crowdfunding (Reg CF), which went into effect in May 2016 and allows early-stage businesses to sell securities to the general public, including non-accredited investors. Initially, startups raising capital under Reg CF could raise up to $\$ 1$ million per 12-month period; this limit was increased to $\$ 5$ million effective March 2021. Rossi et al. (2021) discuss the regulatory

\footnotetext{
${ }^{17}$ The Act also exempts shareholders who receive shares under an employee compensation plan from this count.
} 
environment surrounding equity crowdfunding in the U.S. and compare it to the U.K., where equity crowdfunding has been regulated since 2000 .

Taken together, the regulatory changes that have impacted the private equity market over the last quarter century have likely helped increase the supply of private capital—particularly when combined with the other changes affecting private investors discussed below.

\subsubsection{Changes affecting investors in private markets}

The private market investor landscape has changed substantially over the last two decades. At the early-stage level, accelerators and incubators, which emerged in the mid-2000s, help entrepreneurs raise low-dilution capital to experiment and build their first product, while also providing mentorship and networking support (Cohen et al. 2019). In addition, companies such as AngelList, Aumni, and Carta have introduced new online platforms for private markets that reduce search and informational frictions both between investors and startups, and between GPs and LPs. An increase in the fraction of wealth owned by the upper-tail of the wealth distribution (Smith et al. 2021) — including former employees of startups that went public during the late 1990s dot-com boom - may have further contributed to increase the supply of angel capital. Many U.S. states have sought to further spur angel investments via tax credits - with seemingly little effect on entrepreneurial activity (Denes et al. 2021).

These new organizations and platforms - alongside the regulatory changes that have facilitated them, discussed above-have contributed to a marked increase in the number of fundraising options available to early-stage startups since 2002 (Table 1, rows 15-18). In particular, after a delayed start relative to much of Europe and Australia likely due to the lack of a regulatory framework prior to Reg $\mathrm{CF}$, equity crowdfunding may be finally taking off in the U.S., with an aggregate $\$ 244$ million raised in 2020 (Cumming et al. 2021). That said, the jury is still out on the real effects and staying power of some of these innovations.

Startups raising mid- and late-stage rounds usually do so via a financial intermediarytraditionally, a VC fund. Table 1, row 5 shows that the dollar amount raised by VC funds increased by a factor of 3.5 from 2002 to 2019 , from $\$ 14.7$ billion to $\$ 52.3$ billion. ${ }^{18}$ This

\footnotetext{
${ }^{18}$ All dollar figures are real dollars of 2012 purchasing power.
} 
increase has coincided with an $84 \%$ rise in the number of active VC firms (row 19) and a sharp decline in the median VC fund size since 2008 (row 7), perhaps as a result of new VCs raising relatively small funds to avoid the increasingly crowded late-stage market (see below).

During the same 2002-2019 period, so-called growth-equity investments made by PE funds in late-stage startups have increased by a factor of 7.8 (row 13), reaching $\$ 51.8$ billion in 2019nearly the same amount raised by all VC funds that year. The fact that PE investors have broadened their interest from their traditional focus on leveraged buyouts to growth-equity investments is important, as the PE industry is larger and has grown faster than the VC industry: in 2019, PE funds raised $\$ 304$ billion (row 6), 5.8 times the amount raised by VCs. The capital available to invest in private equity is even larger when considering "alternative vehicles" such as co-investment vehicles and parallel funds, which have grown markedly since the late 1990s (Lerner et al. 2022).

What explains the growth in VC and PE fundraising? While there are undoubtedly multiple factors, one notable driver has been the increase in allocations to private equity by institutional investors such as public pension funds and higher-education endowments: From 2002 to 2019, the average allocation to private equity by public pension funds increased from $2 \%$ to $7 \%$; for endowments, the relative increase was similar, from $5.5 \%$ to $20 \%$ (rows $8-9$ ). What drives these allocation increases? The regulatory changes discussed in Section 3.2.1 have likely played a role. Beyond that, here we highlight an explanation focused on public pension funds, which are among the largest investors in private equity (Lerner et al. 2007) —while emphasizing that more research is needed to fully understand these changes.

The public pension funding gap - the difference between the liabilities and assets of state and local public pension funds-increased from virtually zero in 2001 to $\$ 1.25$ trillion in 2019 (Pew $2015,2021)$. One potential strategy to attempt to shrink the gap is to shift a fund's investment portfolio toward higher return (and higher risk) investments, and private equity has been a popular option. This choice has likely been reinforced by the fact that public pension funds assign the highest expected return of all asset classes in their portfolio to private equity (VC and PE), with a mean expected net return of $12 \%$ (Andonov \& Rauh 2021, Table 1A, arithmetic 
basis). This expected return looks even more enticing when compared to the decline in the 10year Treasury rate from 5.2\% in January 2001 to $1.5 \%$ in January 2020 (FRED 2021).

More generally, part of the growth in the supply of private equity may also reflect a (difficult to empirically identify) "returns chasing" phenomenon, whereby investors increase their allocations to the $\mathrm{VC} / \mathrm{PE}$ asset class in response to its (real or perceived) outperformance over public markets - perhaps best exemplified by the strong performance of the Yale endowment (Lerner et al. 2008). VC funds raised in the mid-1990s did perform exceedingly well: performance peaked for the 1996 vintage, when the average VC fund's net-of-fees return was 4.17 times higher than if the same cash flow stream had been invested in the S\&P 500 public market index (Harrris et al. 2020, Table 1, PME). However, the performance of VC funds from the 1999 through 2006 vintages was lackluster, with the average fund underperforming the S\&P 500 in all but the 2003 vintage. ${ }^{19}$ Only after 2006 did the average fund again consistently beat the S\&P 500, but VC performance remained a far cry from the 1990s heights: in the average year from 2007 through 2014, the average VC fund's return was 1.26 times higher than if the same cash flows had been invested in the S\&P $500 .^{20}$

Thus, the more modest - if not outright disappointing — average performance of VC funds in the last two decades has not stopped the continued growth of the private equity asset class. The growth in private equity allocations may still be justified if LPs believe that they have access to top-quartile funds, whose strong performance tends to be persistent and has more than doubled that of the same cash flows invested in the S\&P 500 even after 2000 (Harris et al. 2020, Table 2) - though of course not all investors can invest in top funds. Furthermore, the performance of private equity relative to public equity can be sensitive to the choice of benchmark, and questions have been raised about the extent to which the fees earned by private equity fund managers are justified (Phalippou 2020). Understanding the role that the performance expectations of private

\footnotetext{
${ }^{19}$ The poor average performance of VC funds from the 1999 and 2000 vintages is particularly noteworthy on a value-weighted basis, as these were the two vintages with the largest number of funds raised and with the second and third largest average amount of capital committed per fund during the 1984-2014 period analyzed by Harris et al. (2020).

${ }^{20}$ The performance of funds from more recent vintages is not yet known, as most of their capital remains invested. The average performance of PE (buyout) funds over time has been far less volatile, with the average fund's cash flows 1.18 times higher than if invested in the S\&P 500 in the average year from 1992 through 2014 (Harrris et al. 2020, Table 1).
} 
versus public equity have played in driving the growth in private markets, the extent to which these expectations are justified by reality, and how the continued growth in the supply of capital to $\mathrm{VC}$ and PE funds may affect their future performance remain exciting research areas.

In parallel with the growth in investments by $\mathrm{VC}$ and $\mathrm{PE}$ funds, the investor side of the latestage private equity market has experienced a second major change over the last two decades: a surge in investments by traditional public market investors such as mutual funds and hedge funds (Aragon et al. 2018, Kwon et al. 2020, Agarwal et al. 2021, Chernenko et al. 2021, Huang et al. 2021). Indeed, the number of late-stage financings that included a mutual fund or a hedge fund grew from 91 in 2002 to 593 in 2019 (row 21). ${ }^{21}$

What explains the increased interest of mutual and hedge funds in late-stage private markets? For one, the decline in IPOs discussed in Section 3.1 means that the kinds of firms that used to go public in the 1990s are now often still private. Thus, if mutual and hedge funds want to continue investing in such firms, they need to look for them in the (late-stage) private equity market. Another potential explanation may be found in the surge of low-fee, passively managed mutual and exchange traded funds since the mid-1990s (Anadu et al. 2020). Investing in private firms, which are excluded from the indices typically tracked by passive funds, may help active funds beat the returns of their passive counterparts, at least on a non-risk-adjusted basis - thereby helping justify the active funds' higher fees. While there is anecdotal evidence that this strategy can be successful (Chung 2021), more research is needed to understand the causes and consequences of mutual and hedge funds' growing interest in private firms.

\subsubsection{Changes affecting startups and their founders}

We conclude our description of the changes in the private equity market by turning our attention to startups - the demand side of the market. A natural first question is: How has the number of new startups seeking to raise private capital changed? The evidence here is mixed. On the one hand, Decker et al.'s (2016) analysis of Census Bureau data indicates that there has been a

\footnotetext{
${ }^{21}$ Sovereign wealth funds are also active in private equity, but their investments are harder to quantify (Bernstein et al. 2013).
} 
decline in the number of high-growth startups since 2000, with startups contributing less to U.S. job creation in the post-2000 period than before.

On the other hand, Guzman \& Stern's (2020) analysis, which attempts to account for the quality of startups, paints a somewhat different picture: They find that while the number of startups that they identify as having high growth potential peaked in 2000 and then fell dramatically with the dot-com bust, starting in 2010 there has been a sharp upward swing. Our own analysis in Table 1 shows that the unique number of startups raising their first $\mathrm{VC}$ round went from 672 in 2002 to 2,769 in 2019 (row 2).

The demand for private capital is affected not just by the number of new startups seeking to raise capital but also by their capital needs. In fact, technological innovations appear to have decreased startups' capital needs, particularly during the initial, experimental stage of the entrepreneurial process. For example, cloud computing's emergence in 2006 makes it possible for new startups to build software products without significant upfront investments, allowing them to raise smaller initial financing rounds (Ewens et al. 2018). Innovations such as CRISPR, a low-cost gene editing technology (Plumer et al. 2018), could have a similar impact in the biotechnology industry. Startups' ability to raise smaller initial rounds makes it possible for investors to follow a "spray and pray" investment approach, making small investments in many high-risk startups (Ewens et al. 2018, Lerner \& Nanda 2020).

Compared to late-stage rounds, early-stage capital tends to be relatively expensive due to the unproven nature of early-stage businesses. Being able to raise smaller initial funding rounds allows those startups that grow up to be successful to do so with less founder dilution - and thus more founder control - than if they had had to raise a larger initial round.

Another technological trend that has affected startups' demand for capital has been the growth in R\&D investments and intangible assets over the last 40 years (Eisfeldt \& Papanikolaou 2013, Kahle \& Stulz 2017, Ewens et al. 2020). To the extent that R\&D intensive firms face greater disclosure costs and are more sensitive to the two-audiences problem discussed in Section 2.3.2, this growth would suggest that the benefits of raising private capital have increased (Farre-Mensa 2017, Doidge et al. 2018, Stulz 2020). 
The desirability of staying private will further increase if it becomes easier for entrepreneurs to sell some of their shares without going public. There have been some advances in this respect, particularly with the emergence since 2009 of platforms that facilitate private securities transactions, such as SharesPost and Nasdaq Private Market (Ibrahim 2012, Larcker et al. 2018). While increasing, the number of secondary transactions in these platforms remains low (row 28), and so it is still unclear how these developments will impact private capital markets.

One countervailing technological trend may have decreased the demand for private capital, while at the same time also contributing to the decline in the number of IPOs and listed firms: An increase in economies of scope, which would increase the benefits for small firms of selling out to larger, typically public, competitors relative to continuing to operate as independent firms (Gao et al. 2013, Eckbo \& Lithell 2021).

\subsection{A new equilibrium in the entrepreneurial finance market}

Taken together, the changes discussed above suggest that the demand for private capital is likely to have increased over the last two decades, particularly by late-stage startups. On the supply side, the growth in investments by non-traditional startup investors such as PE funds, mutual funds, and hedge funds - in part explained by the competitive pressures they and their own investors face - should have led to an increase in the supply of private capital, again concentrated in late-stage rounds.

The data support these predictions. Table 1, row 4 shows that the capital raised by VCbacked private startups grew from $\$ 28.9$ billion in 2002 to $\$ 118.2$ billion in 2019. Importantly, much of this growth has been fueled by late-stage financings (rounds $\mathrm{C}$ and above), whose share of all private financings grew from $50 \%$ in 2002 to $68 \%$ in 2019 (row 12). These late-stage rounds are increasingly likely to contain non-traditional startup investors (row 22).

Interestingly, since 2017, the aggregate annual dollar amount raised in private financings has surpassed the combined amount raised by public firms via IPOs and SEOs, with the aggregate magnitude of late-stage financings alone being similar to all the capital raised via the public markets (Figure 1, Panel A). The latter comparison is particularly relevant, as many of the private firms now raising late-stage rounds would probably have already gone public and would thus be raising public capital three decades ago. Consistent with this, when firms now do go 
public, they are older and have raised more private capital than in the 1990s or the early $2000 \mathrm{~s}$ (rows 33-34; Ewens \& Farre-Mensa 2020).

One final comparison illustrates the extent to which the private markets have become a viable substitute for the public markets. From 1990-2000, the $90^{\text {th }}$ percentile of IPO offering size was $\$ 99$ million. While in 2002 there were only 6 private financing rounds where firms raised more than $\$ 99$ million, the number of such large financing rounds grew 31-fold to 189 in 2019 (row 14); by contrast, there were only 112 IPOs in 2019.

We now turn our attention to valuations - a notoriously challenging exercise in private markets. The average pre-money valuation of the firms that raised their Series A financing round in 2002 was $\$ 10.3$ million; by 2019, it had grown to $\$ 34.1$ million (row 23). ${ }^{22}$ Under the (strong) assumption that firms raising a Series A round in 2002 and 2019 were similar and obtained similar terms, this growth suggests that private valuations increased by $231 \%$ between those years. During the same period, the average pre-money valuation for firms raising a Series $\mathrm{C}$ round increased from $\$ 44$ million to $\$ 145.4$ million, a nearly identical 230\% increase (row 24). The prevalence of "unicorns"-companies with valuations above \$1 billion-also grew markedly during these years, from 0 in 2012 to 130 in 2019 (row 27).

The seemingly larger valuations at which private firms raise capital—combined with startups' smaller capital needs, particularly in early stages (Section 3.2.3) - have induced a marked decline in the fraction of equity firms need to sell to investors in exchange for the capital: In Series As, the average stake sold to investors fell from $46 \%$ in 2002 to $30 \%$ in 2019 (row 25). In Series Cs, the decline was from $33 \%$ to $22 \%$ (row 26).

As noted above, VCs and other startup investors virtually always receive (convertible) preferred stock with a complex set of cash flow and control rights. This raises the question: Do startups' higher valuations come at the expense of an increase in the use of contracting features offering downside protection to investors? Perhaps surprisingly, this is not the case: The use of investor-friendly contracting features such as participating preferred stock, large liquidation preferences, and cumulative dividends all declined from 2002 to 2019 (rows 29-31).

\footnotetext{
${ }^{22}$ A startup's pre-money valuation is its valuation without including the money raised in the financing round. The valuations reported here follow industry practice and do not account for Gornall \& Strebulaev's (2020) concerns.
} 
Nor do investors receive more control rights - in fact, the opposite appears to be the case. Ewens \& Malenko (2021) show that 37\% of all the Series A financing rounds raised in 2002 resulted in VCs controlling the startup's board of directors; in 2017, that fraction had declined to 10\% (row 32 and Figure 1, Panel B). Furthermore, Ewens \& Farre-Mensa (2020) show that the use of redemption rights in Series A rounds, which allow investors to trigger an exit by forcing startups to repurchase their shares after a specified time period, has also declined markedly since the early 2000 s.

Investors' lower control rights and smaller stakes mean that entrepreneurs now enjoy greater bargaining power vis-à-vis investors at the time of making exit decisions. Given entrepreneurs' desire to maintain decision-making control (Brau \& Fawcett 2006), their increased bargaining power likely helps explain why many startups are choosing to stay private and independent longer (Ewens \& Farre-Mensa 2020) — even if this means overriding VC investors' preference to exit via an IPO (Black \& Gilson 1998) or an acquisition (Cumming 2008) by the end of their fund's lifecycle.

In sum, the new equilibrium in the entrepreneurial finance market features (1) more private capital invested, particularly in late-stage rounds, and (2) private equity contracts that are more founder-friendly in terms of both cash flow and control rights. What drives these changes? We highlight two potential explanations, while noting that more research is needed to fully understand all the forces behind this new equilibrium.

First, the new equilibrium suggests that the increase in the supply of private capital over the last two decades has outstripped the increase in the demand for it, leading to better terms for entrepreneurs in an increasingly "money chasing deals" (Gompers \& Lerner 2000) environment. ${ }^{23}$ Second, compared to VC investors, some of the non-traditional startup investors that have driven much of the increase in the supply of late-stage private capital may have a lower after-fee cost of capital and/or a lower preference for control rights (Chernenko et al. 2021).

\footnotetext{
${ }^{23} \mathrm{VC}$ funds' current historically high levels of dry powder (row 10) support this interpretation.
} 


\section{Conclusions and future research}

The U.S. entrepreneurial finance market has changed dramatically over the last two decades. The number of listed firms has fallen sharply. At the same time, capital has flowed to the private markets, particularly in late-stage rounds, both via traditional startup investors such as $\mathrm{VC}$ funds and via non-traditional investors such as PE, mutual, and hedge funds. This new equilibrium in the entrepreneurial finance market features seemingly higher valuations for private firms and more founder-friendly contracts.

In this article, we provide an intellectual framework to think through these changes by outlining the differences between public and private firms. Armed with this framework, we then attempt to identify the shifts in supply and demand forces that have given rise to this new equilibrium. But, as we have noted throughout the text, more research is needed to establish strong causal relationships between these shifts and the new equilibrium outcomes.

We conclude by listing some open research questions motivated by the facts we have documented:

- What is the connection between higher startup valuations and more founder-friendly contracts, and the returns earned by the private equity asset class (Harris et al. 2020)? More generally, how will the growth of private markets affect investor returns?

- How do the changes in the late-stage financing market impact the traditional VC investing model?

- Has the increased availability of private capital changed the characteristics of individuals becoming entrepreneurs?

- What are the real consequences of the decline in U.S. listings and the growth of the private equity market? Several papers have analyzed the differences between how public and private firms invest and innovate (e.g., Asker et al. 2015, Bernstein 2015), but identification and external validity are challenging in this literature.

- How (if at all) should regulators respond to the continued growth in the private capital markets? Several policymakers and regulators have voiced concerns about this growth, 
pointing in particular to the greater oversight and transparency under which public firms operate (e.g., Obama 2012, Kiernan 2022).

- How do the patterns and trade-offs discussed here for the U.S. apply in other countries?

- How can other countries foster a thriving entrepreneurial finance market, particularly for late-stage startups? To illustrate, a recent European Commission (2018) report notes that in the EU, "later-stage financing in particular remains restricted" (p. 228). 


\section{References}

Abudy, Menachem, Simon Benninga, and Efrat Shust. 2016. "The Cost of Equity for Private Firms." Journal of Corporate Finance 37: 431-43.

Agarwal, Vikas, Brad Barber, Si Cheng, Allaudeen Hameed, and Ayako Yasuda. 2021. "Private Company Valuations by Mutual Funds." Working Paper.

Aghamolla, Cyrus, and Richard T Thakor. Forthcoming. "Do Mandatory Disclosure Requirements for Private Firms Increase the Propensity of Going Public?" Journal of Accounting Research, Forthcoming.

Akhigbe, Aigbe, and Ann Marie Whyte. 2015. "SEO Announcement Returns and Internal Capital Market Efficiency." Journal of Corporate Finance 31: 271-83.

Anadu, Kenechukwu, Mathias Kruttli, Patrick McCabe, and Emilio Osambela. 2020. "The Shift from Active to Passive Investing: Risks to Financial Stability?" Financial Analysts Journal 76 (4): 23-39.

Andonov, Aleksandar, and Joshua D Rauh. 2021. "The Return Expectations of Public Pension Funds." Working Paper.

Aragon, George O, Emma Li, and Laura Anne Lindsey. 2018. "Exploration or Exploitation? Hedge Funds in Venture Capital." Working Paper.

Asker, John, Joan Farre-Mensa, and Alexander Ljungqvist. 2015. "Corporate Investment and Stock Market Listing: A Puzzle?” Review of Financial Studies 28 (2): 342-90.

Badertscher, Brad A, Dan Givoly, Sharon P Katz, and Hanna Lee. 2019. "Private Ownership and the Cost of Public Debt: Evidence from the Bond Market." Management Science 65 (1): 301-26.

Baker, Malcolm, and Jeffrey Wurgler. 2013. "Behavioral Corporate Finance: An Updated Survey." In Handbook of the Economics of Finance, 2:357-424. Elsevier.

Bauguess, Scott, Rachita Gullapalli, and Vladimir Ivanov. 2018. "Capital Raising in the U.S.: An Analysis of the Market for Unregistered Securities Offerings, 2009-2017." Working Paper.

Bernstein, Shai. 2015. “Does Going Public Affect Innovation?” Journal of Finance 70 (4): 1365-1403.

Bernstein, Shai, Xavier Giroud, and Richard R Townsend. 2016. "The Impact of Venture Capital Monitoring." Journal of Finance 71 (4): 1591-1622.

Bernstein, Shai, Josh Lerner, and Antoinette Schoar. 2013. "The Investment Strategies of Sovereign Wealth Funds.” Journal of Economic Perspectives 27 (2): 219-38.

Bhattacharya, Sudipto, and Jay R Ritter. 1983. "Innovation and Communication: Signalling with Partial Disclosure.” Review of Economic Studies 50 (2): 331-46.

Billett, Matthew T, Ioannis V Floros, and Jon A Garfinkel. 2019. "At-the-Market Offerings." Journal of Financial and Quantitative Analysis 54 (3): 1263-83. 
Black, Bernard S, and Ronald J Gilson. 1998. "Venture Capital and the Structure of Capital Markets: Banks Versus Stock Markets.” Journal of Financial Economics 47 (3): 243-77.

Bodnaruk, Andriy, Eugene Kandel, Massimo Massa, and Andrei Simonov. 2008. "Shareholder Diversification and the Decision to Go Public." Review of Financial Studies 21 (6): 2779-2824.

Brau, James C, and Stanley E Fawcett. 2006. "Initial Public Offerings: An Analysis of Theory and Practice." Journal of Finance 61 (1): 399-436.

Brennan, Michael J, and Walter N Torous. 1999. "Individual Decision Making and Investor Welfare." Economic Notes 28 (2): 119-43.

Brüggemann, Ulf, Aditya Kaul, Christian Leuz, and Ingrid M Werner. 2018. "The Twilight Zone: OTC Regulatory Regimes and Market Quality.” Review of Financial Studies 31 (3): 898942.

Campagna, Louis J. 2020. "Information Letter 06-03-2020." https://www.dol.gov/agencies/ebsa/about-ebsa/our-activities/resource-center/informationletters/06-03-2020.

Celikyurt, Ugur, Merih Sevilir, and Anil Shivdasani. 2010. "Going Public to Acquire? The Acquisition Motive in IPOs.” Journal of Financial Economics 96 (3): 345-63.

Chemmanur, Thomas J, Shan He, and Debarshi K Nandy. 2010. "The Going-Public Decision and the Product Market." Review of Financial Studies 23 (5): 1855-1908.

Chen, Jun, and Michael Ewens. 2021. "Venture Capitalists' Access to Finance and Its Impact on Startups." Working Paper.

Chernenko, Sergey, Josh Lerner, and Yao Zeng. 2021. "Mutual Funds as Venture Capitalists? Evidence from Unicorns.” Review of Financial Studies 34 (5): 2362-2410.

Chod, Jiri, and Evgeny Lyandres. 2011. "Strategic IPOs and Product Market Competition." Journal of Financial Economics 100 (1): 45-67.

Chung, Juliet. 2021. "As Hedge Funds Endure Rocky Year, Private-Company Bets Ease the Pain." Wall Street Journal (October 23).

Coates, John C, and Suraj Srinivasan. 2014. "SOX After Ten Years: A Multidisciplinary Review." Accounting Horizons 28 (3): 627-71.

Cohen, Susan, Daniel C Fehder, Yael V Hochberg, and Fiona Murray. 2019. "The Design of Startup Accelerators." Research Policy 48 (7): 1781-97.

Cumming, Douglas J. 2008. Contracts and Exits in Venture Capital Finance. Review of Financial Studies 21 (5): 1947-82.

Cumming, Douglas J, Sofia Johan, and Robert S Reardon. 2021. "Governance and Success in U.S. Securities-Based Crowdfunding." Working Paper.

Da Rin, Marco, Thomas Hellmann, and Manju Puri. 2013. "A Survey of Venture Capital Research." In Handbook of the Economics of Finance, 2: 573-648. Elsevier. 
Decker, Ryan A, John Haltiwanger, Ron S Jarmin, and Javier Miranda. 2016. "Where Has All the Skewness Gone? The Decline in High-Growth (Young) Firms in the U.S." European Economic Review 86, 4-23.

Denes, Matthew R, Sabrina T Howell, Filippo Mezzanotti, Xinxin Wang, and Ting Xu. 2021. "Investor Tax Credits and Entrepreneurship: Evidence from US States." Working Paper.

Dodhia, Parash. 2020. "SEC Modernizes the Accredited Investor Definition." https://www.eisneramper.com/sec-accredited-investor-ea-1220/.

Doidge, Craig, Kathleen M Kahle, G Andrew Karolyi, and René M Stulz. 2018. "Eclipse of the Public Corporation or Eclipse of the Public Markets?" Journal of Applied Corporate Finance 30 (1): 8-16.

Doidge, Craig, G Andrew Karolyi, and René M Stulz. 2013. "The US Left Behind? Financial Globalization and the Rise of IPOs Outside the US." Journal of Financial Economics 110 (3): 546-73.

Doidge, Craig, G Andrew Karolyi, and René M Stulz. 2017. “The US Listing Gap.” Journal of Financial Economics 123 (3): 464-87.

Dow, James, and Gary Gorton. 1997. "Stock Market Efficiency and Economic Efficiency: Is There a Connection?" Journal of Finance 52 (3): 1087-1129.

Eckbo, B Espen, and Markus Lithell. 2022. "Merger-Driven Listing Dynamics.” Working Paper.

Effron, Samuel A. 2016. "The New Section 4(a)(7): More Than a Codification of Section '4(a)(11/2)'”. https://www.mintz.com/insights-center/viewpoints/2016-01-21-new-section-4a7more-codification-section-4a1-12.

Eisfeldt, Andrea L, and Dimitris Papanikolaou. 2013. "Organization Capital and the CrossSection of Expected Returns." Journal of Finance 68 (4): 1365-1406.

European Commission. 2018. "Science, Research and Innovation Performance of the EU, 2018."

Ewens, Michael, and Joan Farre-Mensa. 2020. "The Deregulation of the Private Equity Markets and the Decline in IPOs." Review of Financial Studies 33 (12): 5463-5509.

Ewens, Michael, and Nadya Malenko. 2021. "Board Dynamics over the Startup Life Cycle." Working Paper.

Ewens, Michael, Ramana Nanda, and Matthew Rhodes-Kropf. 2018. "Cost of Experimentation and the Evolution of Venture Capital." Journal of Financial Economics 128 (3): $422-42$.

Ewens, Michael, Ryan H Peters, and Sean Wang. 2020. "Measuring Intangible Capital with Market Prices." Working Paper.

Ewens, Michael, Kairong Xiao, and Ting Xu. 2021. "Regulatory Costs of Being Public: Evidence from Bunching Estimation." Working Paper. 
Farre-Mensa, Joan. 2017. "The Benefits of Selective Disclosure: Evidence from Private Firms." Working Paper.

FRED. 2021. "Market Yield on U.S. Treasury Securities at 10-Year Constant Maturity."

Gahng, Minmo, Jay R Ritter, and Donghang Zhang. 2021. “SPACs.” Working Paper.

Gao, Xiaohui, Jay R Ritter, and Zhongyan Zhu. 2013. "Where Have All the IPOs Gone?" Journal of Financial and Quantitative Analysis 48 (6): 1663-92.

Gompers, Paul. 1996. "Grandstanding in the Venture Capital Industry." Journal of Financial Economics 42 (1): 133-56.

Gompers, Paul, and Josh Lerner. 2000. "Money Chasing Deals? The Impact of Fund Inflows on Private Equity Valuations." Journal of Financial Economics 55 (2): 281-325.

Google. 2004. Form S-1 dated April 29. https://www.sec.gov/Archives/edgar/data/1288776/000119312504073639/ds1.htm.

Gornall, Will, and Ilya A Strebulaev. 2020. "Squaring Venture Capital Valuations with Reality.” Journal of Financial Economics 135 (1): 120-43.

Gredil, Oleg, Yan Liu, and Berk A Sensoy. 2021. "Diversifying Private Equity." Working Paper.

Gustafson, Matthew T, and Peter Iliev. 2017. "The Effects of Removing Barriers to Equity Issuance.” Journal of Financial Economics 124 (3): 580-98.

Guzman, Jorge, and Scott Stern. 2020. "The State of American Entrepreneurship: New Estimates of the Quantity and Quality of Entrepreneurship for 32 US States, 1988-2014." American Economic Journal: Economic Policy 12 (4): 212-43.

Harmetz, Lloyd S., and Bradley Berman. 2017. "Frequently Asked Questions about Shelf Offerings." https://media2.mofo.com/documents/faqshelfofferings.pdf.

Harris, Robert S, Tim Jenkinson, Steven N Kaplan, and Ruediger Stucke. 2020. 'Has Persistence Persisted in Private Equity? Evidence from Buyout and Venture Capital Funds." Working Paper.

Heaton, John, and Deborah Lucas. 2004. "Capital Structure, Hurdle Rates, and Portfolio Choice Interactions in an Entrepreneurial Firm.” Working Paper.

Hermalin, Benjamin, and Michael Weisbach. 2017. The Handbook of the Economics of Corporate Governance. Vol. 1. Elsevier.

Holmström, Bengt, and Jean Tirole. 1993. "Market Liquidity and Performance Monitoring." Journal of Political Economy 101 (4): 678-709.

Hsieh, Jim, Evgeny Lyandres, and Alexei Zhdanov. 2011. "A Theory of Merger-Driven IPOs.” Journal of Financial and Quantitative Analysis 46 (5): 1367-1405.

Huang, Shiyang, Yifei Mao, Cong Wang, and Dexin Zhou. 2021. "Public Market Players in the Private World: Implications for the Going-Public Process." Review of Financial Studies 34 (5): 2411-47. 
Ibrahim, Darian M. 2012. "The New Exit in Venture Capital." Vanderbilt Law Review 65: 147.

Jensen, Michael C, and William H Meckling. 1976. "Theory of the Firm: Managerial Behavior, Agency Costs and Ownership Structure." Journal of Financial Economics 3 (4): 30560 .

Johnson, Eric, Michael Blankenship, Ben Smolij, and John Niedzwiecki. 2020. "Market Trends 2019/20: Follow-on Offerings."

https://www.winston.com/images/content/2/0/v2/202821/Market-Trends-201920-Follow-OnOfferings.pdf.

Kahle, Kathleen M, and René M Stulz. 2017. "Is the US Public Corporation in Trouble?" Journal of Economic Perspectives 31 (3): 67-88.

Kerr, William R, Josh Lerner, and Antoinette Schoar. 2014. "The Consequences of Entrepreneurial Finance: Evidence from Angel Financings." Review of Financial Studies 27 (1): $20-55$.

Kiernan, Paul. 2022. "SEC Pushes for More Transparency From Private Companies." Wall Street Journal (January 10).

Kim, Woojin, and Michael S Weisbach. 2008. "Motivations for Public Equity Offers: An International Perspective." Journal of Financial Economics 87 (2): 281-307.

Koeplin, John, Atulya Sarin, and Alan C Shapiro. 2000. "The Private Company Discount." Journal of Applied Corporate Finance 12 (4): 94-101.

Kovner, Anna, and Chenyang Jason Wei. 2014. "The Private Premium in Public Bonds." Working Paper.

Kwon, Sungjoung, Michelle Lowry, and Yiming Qian. 2020. "Mutual Fund Investments in Private Firms." Journal of Financial Economics 136 (2): 407-43.

La Porta, Rafael, Florencio Lopez-de-Silanes, and Andrei Shleifer. 1999. "Corporate Ownership Around the World." Journal of Finance 54 (2): 471-517.

Larcker, David F, Brian Tayan, and Edward M Watts. 2018. "Cashing It In: PrivateCompany Exchanges and Employee Stock Sales Prior to IPO." Working Paper.

Lawson, Kurt L. P. 2006. "Pension Protection Act of 2006 Allows Private Equity Funds to Accept More Foreign and Governmental Plan Contributions Without Becoming Subject to ERISA." https://www.mondaq.com/unitedstates/workforce-management/42508/pensionprotection-act-of-2006-allows-private-equity-funds-to-accept-more-foreign-and-governmentalplan-contributions-without-becoming-subject-to-erisa.

Lerner, Josh, Jason Mao, Antoinette Schoar, and Nan R Zhang. 2022. "Investing Outside the Box: Evidence from Alternative Vehicles in Private Equity." Journal of Financial Economics 143 (1): 359-80.

Lerner, Josh, and Ramana Nanda. 2020. "Venture Capital's Role in Financing Innovation: What We Know and How Much We Still Need to Learn." Journal of Economic Perspectives 34 (3): 237-61. 
Lerner, Josh, Antoinette Schoar, and Jialan Wang. 2008. "Secrets of the Academy: The Drivers of University Endowment Success.” Journal of Economic Perspectives 22 (3): 207-22.

Lerner, Josh, Antoinette Schoar, and Wan Wongsunwai. 2007. "Smart Institutions, Foolish Choices: The Limited Partner Performance Puzzle.” Journal of Finance 62 (2): 731-64.

Lindsey, Laura Anne, and Luke CD Stein. 2020. "Angels, Entrepreneurship, and Employment Dynamics: Evidence from Investor Accreditation Rules.” Working Paper.

Loderer, Claudio, and Urs Waelchli. 2010. "Protecting Minority Shareholders: Listed Versus Unlisted Firms." Financial Management 39 (1): 33-57.

Longstaff, Francis A. 1995. "How Much Can Marketability Affect Security Values?" Journal of Finance 50 (5): 1767-74.

Lowry, Michelle. 2003. "Why Does IPO Volume Fluctuate so Much?” Journal of Financial Economics 67 (1): 3-40.

Lowry, Michelle, Roni Michaely, and Ekaterina Volkova. 2017. "Initial Public Offerings: A Synthesis of the Literature and Directions for Future Research." Foundations and Trends in Finance 11 (3-4): 154-320.

Maksimovic, Vojislav, and Pegaret Pichler. 2001. "Technological Innovation and Initial Public Offerings.” Review of Financial Studies 14 (2): 459-94.

Metrick, Andrew, and Ayako Yasuda. 2021. Venture Capital and the Finance of Innovation. John Wiley \& Sons.

Morrison \& Foerster. 2018. "Frequently Asked Questions about Period Reporting Requirements for U.S. Issuers - Overview." https://media2.mofo.com/documents/faq-periodicreporting-requirements-for-us-issuers-overview.pdf.

Nasdaq. 2021. "Rulebook - The Nasdaq Stock Market." https://listingcenter.nasdaq.com/rulebook/nasdaq/rules.

NYSE. 2021. "Listings - Company Resources.” https://www.nyse.com/listings/resources.

Obama, Barack. 2012. "Remarks by the President at JOBS Act Bill Signing." https://obamawhitehouse.archives.gov/the-press-office/2012/04/05/remarks-president-jobs-actbill-signing.

Officer, Micah S. 2007. "The Price of Corporate Liquidity: Acquisition Discounts for Unlisted Targets." Journal of Financial Economics 83 (3): 571-98.

Pagano, Marco, Fabio Panetta, and Luigi Zingales. 1998. "Why Do Companies Go Public? An Empirical Analysis." Journal of Finance 53 (1): 27-64.

Pew. 2015. "The State Pensions Funding Gap: Challenges Persist." https://www.pewtrusts.org/en/research-and-analysis/issue-briefs/2015/07/the-state-pensionsfunding-gap-challenges-persist.

Pew. 2021. "The State Pension Funding Gap: Plans Have Stabilized in Wake of Pandemic." https://www.pewtrusts.org/en/research-and-analysis/issue-briefs/2021/09/the-state-pensionfunding-gap-plans-have-stabilized-in-wake-of-pandemic. 
Phalippou, Ludovic. 2020. "An Inconvenient Fact: Private Equity Returns and the Billionaire Factory." Journal of Investing 30 (1): 11-39.

Phalippou, Ludovic, Christian Rauch, and Marc Umber. 2018. "Private Equity Portfolio Company Fees." Journal of Financial Economics 129 (3): 559-85.

Plumer, Brad, Eliza Barclay, Julia Belluz, and Umair Irfan. 2018. “A Simple Guide to CRISPR, One of the Biggest Science Stories of the Decade." Vox (December 27).

Puri, Manju, and Rebecca Zarutskie. 2012. "On the Life Cycle Dynamics of Venture-Capitaland Non-Venture-Capital-Financed Firms.” Journal of Finance 67 (6): 2247-93.

Ritter, Jay R. 2011. "Equilibrium in the Initial Public Offerings Market." Annual Review of Financial Economics 3 (1): 347-74.

Ritter, Jay R. 2021. “Initial Public Offerings: Updated Statistics.” University of Florida.

Robinson, David T, and Berk A Sensoy. 2013. "Do Private Equity Fund Managers Earn Their Fees? Compensation, Ownership, and Cash Flow Performance." Review of Financial Studies 26 (11): 2760-97.

Rossi, Alice, Tom Vanacker, and Silvio Vismara. 2021. "Equity Crowdfunding: New Evidence from US and UK markets." Review of Corporate Finance 1 (3-4): 407-53

Saunders, Anthony, and Sascha Steffen. 2011. "The Costs of Being Private: Evidence from the Loan Market.” Review of Financial Studies 24 (12): 4091-4122.

SEC. 2009. "Study of the Sarbanes-Oxley Act of 2002 Section 404 Internal Control over Financial Reporting Requirements." https://www.sec.gov/news/studies/2009/sox-404_study.pdf.

SEC. 2013. "Rule 144: Selling Restricted and Control Securities." https://www.sec.gov/reportspubs/investor-publications/investorpubsrule144htm.html.

SEC. 2021. "Exempt Offerings.” https://www.sec.gov/smallbusiness/exemptofferings.

Shane, S. 2008. "The Importance of Angel Investing in Financing the Growth of Entrepreneurial Ventures.” Working Paper.

Shleifer, Andrei, and Robert W Vishny. 1997. “A Survey of Corporate Governance.” Journal of Finance 52 (2): 737-83.

Smith, Matthew, Owen M Zidar, and Eric Zwick. 2021. "Top Wealth in America: New Estimates and Implications for Taxing the Rich." Working Paper.

Stein, Jeremy C. 1989. "Efficient Capital Markets, Inefficient Firms: A Model of Myopic Corporate Behavior.” Quarterly Journal of Economics 104 (4): 655-69.

Stein, Jeremy C. 2003. "Agency, Information and Corporate Investment." Handbook of the Economics of Finance 1: 111-65.

Stulz, René M. 2020. "Public Versus Private Equity." Oxford Review of Economic Policy 36 (2): 275-90.

Sweet, Charles A. 2016. "The FAST Act, New Section 4(a)(7), and Section 4(a)(11/2)." https://www.morganlewis.com/pubs/2016/01/the-fast-act-new-sections. 


\section{Figure 1. Changing financing sources and bargaining power.}

\section{Panel A}

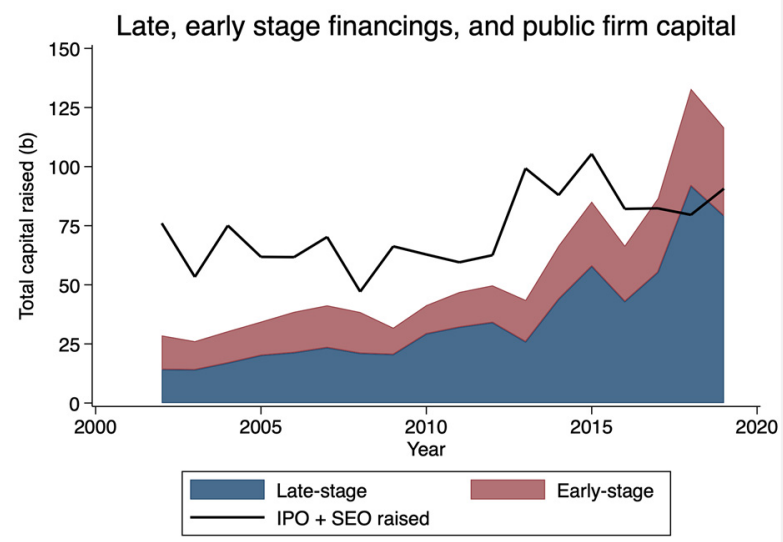

Panel B

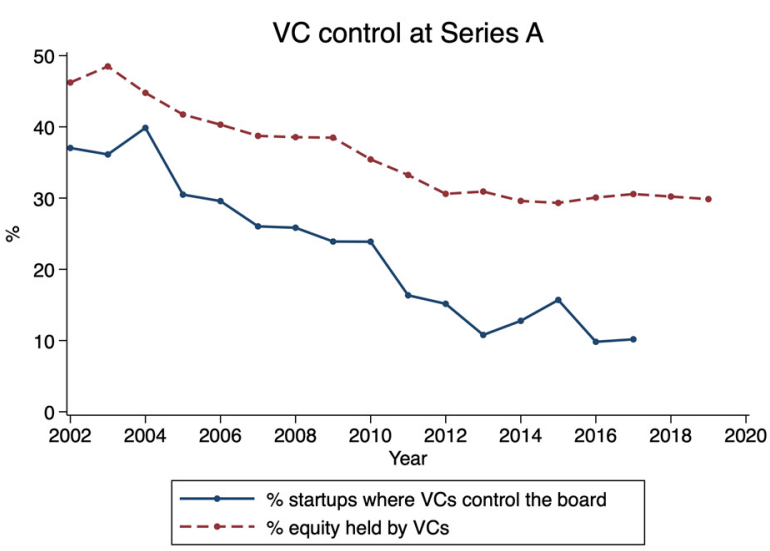

For each year, Panel A shows the total capital raised in IPOs and SEOs by public firms (black solid line) and the total capital raised by VC-backed startups, broken down by stage (red and blue areas). We classify Series A and most Series B rounds as early stage, and Series $\mathrm{C}$ and above as late stage. All dollar figures are real dollars of 2012 purchasing power. Panel B shows the annual fraction of startups where VC investors gain control of the board of directors after the Series A round (blue solid line) as well as the average equity stake held by VC investors at the Series A closing (red dashed line). For data sources and variable definitions (including the precise definition of late-stage round), see Table 1. 
Table 1. Evolution of the entrepreneurial finance market.

\begin{tabular}{|c|c|c|c|c|c|}
\hline & & 2002 & 2008 & 2014 & 2019 \\
\hline 1 & VC-backed startup financing events & 2,750 & 3,691 & 5,741 & 6,335 \\
\hline 2 & Startups raising first VC round & 672 & 1,474 & 2,385 & 2,769 \\
\hline 3 & $\$$ b raised in IPOs and SEOs & $\$ 76.1 \mathrm{~b}$ & $\$ 47.1 \mathrm{~b}$ & $\$ 87.6 b$ & $\$ 90.7 b$ \\
\hline \multirow[t]{2}{*}{4} & \$b raised by VC-backed startups & $\$ 28.9 \mathrm{~b}$ & $\$ 38.9 \mathrm{~b}$ & $\$ 67.3 b$ & $\$ 118.2 b$ \\
\hline & Capital supply & & & & \\
\hline 5 & $\$ b$ raised by VC funds & $\$ 14.7 b$ & $\$ 27.7 b$ & $\$ 36.7 \mathrm{~b}$ & $\$ 52.3 b$ \\
\hline 6 & $\$$ b raised by $\mathrm{PE}$ funds & $\$ 68.1 \mathrm{~b}$ & $\$ 202.8 b$ & $\$ 179 b$ & $\$ 304 b$ \\
\hline 7 & Median VC fund size (\$m) & $\$ 61.3 \mathrm{~m}$ & $\$ 78.6 \mathrm{~m}$ & $\$ 23.3 \mathrm{~m}$ & $\$ 31.7 \mathrm{~m}$ \\
\hline 8 & Public pension funds allocation to VC/PE & $2 \%$ & $4.1 \%$ & $5.4 \%$ & $7 \%$ \\
\hline 9 & High-ed endowments allocation to $\mathrm{VC} / \mathrm{PE}$ & $5.5 \%$ & $11.3 \%$ & $15 \%$ & $19.9 \%$ \\
\hline \multirow[t]{2}{*}{10} & VC funds dry powder $(\$ b)$ & $\$ 122.6 b$ & $\$ 115 b$ & $\$ 103.5 b$ & $\$ 233 b$ \\
\hline & Financing events & & & & \\
\hline 11 & Equity crowdfunding events & 0 & 0 & $179^{*}$ & 1,134 \\
\hline 12 & $\%$ private capital going to late rounds $(\mathrm{C}+)$ & $49.7 \%$ & $54.6 \%$ & $66 \%$ & $68 \%$ \\
\hline 13 & \$b invested by PE funds in growth-equity & $\$ 6.6 \mathrm{~b}$ & $\$ 13.2 b$ & $\$ 30.3 b$ & $\$ 51.8 \mathrm{~b}$ \\
\hline \multirow[t]{2}{*}{14} & Rounds $>\$ 99 \mathrm{~m}$ (90th percentile IPO size) & 6 & 35 & 78 & 189 \\
\hline & Investor pool & & & & \\
\hline 15 & Unique early-stage investors & 1,552 & 1,352 & 2,029 & 2,524 \\
\hline 16 & Financings with angel investors & $\mathrm{n} / \mathrm{a}$ & 709 & 3,657 & 3,125 \\
\hline 17 & Unique accelerators/incubators & 111 & 248 & 787 & 1078 \\
\hline 18 & Equity crowdfunding platforms & 0 & 0 & $23^{*}$ & 34 \\
\hline 19 & Unique venture capital firms & 1,008 & 975 & 1,450 & 1,854 \\
\hline 20 & Unique late-stage investors & 1,486 & 1,275 & 1,484 & 1,960 \\
\hline 21 & Financings with mutual or hedge fund & 91 & 203 & 370 & 593 \\
\hline \multirow[t]{2}{*}{22} & $\%$ late-stage $\$$ from non-traditional investors & $53.9 \%$ & $56.2 \%$ & $68.3 \%$ & $72.8 \%$ \\
\hline & Valuation and liquidity & & & & \\
\hline 23 & Average Series A pre- $\$$ valuation $(\$ \mathrm{~m})$ & $\$ 10.3 \mathrm{~m}$ & $\$ 14.7 \mathrm{~m}$ & $\$ 16.2 \mathrm{~m}$ & $\$ 34.1 \mathrm{~m}$ \\
\hline 24 & Average Series C pre-\$ valuation (\$m) & $\$ 44 m$ & $\$ 64.1 \mathrm{~m}$ & $\$ 124.6 \mathrm{~m}$ & $\$ 145.4 \mathrm{~m}$ \\
\hline 25 & Average equity stake sold in Series A & $46 \%$ & $38 \%$ & $29 \%$ & $30 \%$ \\
\hline 26 & Average equity stake sold in Series C & $33 \%$ & $26 \%$ & $22 \%$ & $22 \%$ \\
\hline 27 & Unicorns (startups with $>\$ 1$ b valuation) & 0 & 5 & 57 & 130 \\
\hline \multirow[t]{2}{*}{28} & Secondary private transactions & 2 & 16 & 44 & 223 \\
\hline & Contracting and governance & & & & \\
\hline 29 & Deals with Participating preferred & $68 \%$ & $55 \%$ & $27 \%$ & $12.2 \%$ \\
\hline 30 & Deals with $>1 \mathrm{X}$ liquidation preference & $12.6 \%$ & $5.6 \%$ & $3.5 \%$ & $0.4 \%$ \\
\hline 31 & Deals with cumulative dividends & $26.7 \%$ & $21.9 \%$ & $17 \%$ & $18 \%$ \\
\hline \multirow[t]{2}{*}{32} & Series A boards controlled by VCs & $37.3 \%$ & $25.8 \%$ & $12.7 \%$ & $10.1 \%^{+}$ \\
\hline & Characteristics at IPO (VC-backed startups) & & & & \\
\hline 33 & Median age & 3.83 & 8.19 & 7.2 & 6.3 \\
\hline 34 & Median pre-IPO \$m raised & $\$ 80.7 \mathrm{~m}$ & $\$ 57.5 \mathrm{~m}$ & $\$ 108.6 \mathrm{~m}$ & $\$ 148.7 \mathrm{~m}$ \\
\hline
\end{tabular}

The table reports statistics on various features of the entrepreneurial finance market for 2002, 2008, 2014 and 2019. All dollar figures are real dollars of 2012 purchasing power. ${ }^{*}$ is for year 2016 and ${ }^{+}$is for year 2017. Variable definitions and data sources (by row): 1-2. Count of unique VC-backed startups raising a financing round (row 1) or their first ever VC round (row 2). Source: VentureSource. 3. Total capital raised in IPOs and SEOs by U.S. non- 
financial firms. Source: Federal Reserve, https://www.federalreserve.gov/releases/efa/efa-project-equity-issuanceretirement.htm. 4. Sum of all private capital raised by VC-backed startups. Source: VentureSource. 5. Capital committed to venture capital funds based in the U.S. For 2002, the source is VentureSource; for 2008 and later years, the source is Pitchbook. 6. Total capital raised by PE (non-VC) funds. Source: Pitchbook. 7. Median size of VC funds raised in each year. Source: Pitchbook. 8. Allocation to VC and PE funds by public pension plans. Source: Public Plans Data, https://publicplansdata.org/public-plans-database/download-full-data-set/\#nav-4. 9. Source: Public data tables at NACUBO, https://www.nacubo.org/Research/2021/Public-NTSE-Tables. For each year, we calculate the sum of the VC and PE allocation percentages (dollar-weighted), where PE excludes real estate. 10. Dry powder is defined as aggregate capital committed to VC funds net of capital already invested. Source: Preqin market reports from Gredil et al. (2021). 11. Count of equity crowdfunding events. The data, extracted from SEC Form Cs, are available at the SEC website: https://www.sec.gov/dera/data/crowdfunding-offerings-data-sets. 12. Percentage of all the dollars invested in equity financing events in VC-backed startups that are invested in late-stage rounds. We classify a round as late-stage if the startup is raising its third (typically, Series C) or later round, with two refinements: (a) If a financing event is a third or later round but VentureSource lists it as "Seed," "Angel," or "Series A," we re-classify it as early-stage; (b) if a financing event is a third or later round but VentureSource lists it as "Series B" and it has been less than four years since the startup's first financing round, we also re-classify it as early-stage. Source: VentureSource. 13. Total dollars invested in growth equity rounds (as defined in the 2016 NVCA report). Source: Pitchbook. 14. Number of financing rounds whose size exceeds $\$ 99$ million raised by VC-backed startups; $\$ 99$ million was the $90^{\text {th }}$ percentile of the offering size of VC-backed IPOs from 1990-2000. Source: VentureSource. 15. Unique number of investors of any type that participated in at least one first or second round financing raised by VC-backed startups that year. Source: VentureSource. 16. Number of financing rounds raised by VC-backed startups that contained at least one investor that Pitchbook characterizes as "angel" or "angel group." Source: Pitchbook. 17. Count determined based on a search of founding dates for U.S. investors whose primary designation is "Accelerator/Incubator." Source: Pitchbook. 18. Count of unique platforms facilitating equity crowdfunding issues. The data, extracted from SEC Form Cs, are available at the SEC website: https://www.sec.gov/dera/data/crowdfunding-offerings-data-sets. 19. Count of venture capital investors (as defined by VentureSource) with at least one investment during the relevant year. Source: VentureSource. 20. Unique number of investors of any type in late-stage rounds. See row 12 for the definition of late-stage round. Source: VentureSource. 21. Number of financing rounds raised by VC-backed startups that contained at least one mutual fund or hedge fund investor in the financing syndicate. Source: Pitchbook. 22. Percentage of all the dollars invested in late-stage rounds (as defined in row 12) that were supplied by non-traditional (non-VC) startup investors (e.g., PE funds, corporations, mutual funds, or hedge funds). When the dollar amounts supplied by some or all of the investors in a financing syndicate are not broken down, we assume equal shares. Source: VentureSource. 23-26: Average Series A (Series C) pre-\$ valuation is the average reported pre-money valuation for Series A (Series C) financing rounds. Average equity stake sold is the as-if-common equity stake sold to all investors in the financing syndicate (i.e., the capital invested divided by the post-money valuation). Source: VentureSource. 27. Unicorn count is the number of VC-backed startups raising financing rounds with a (nominal) post-money valuation above $\$ 1$ billion. Source: VentureSource. 28. Count of secondary transactions involving the shares of privately held U.S.-based VC-backed startups. Source: Pitchbook. 29-31: Percentage of VC financings where investors received preferred stock that featured the relevant contract term, based on the sample of contracts for which contract terms are available. Source: Pitchbook and VCExperts for 2002 and 2008; Pitchbook for the remaining years. 32: Out of all startups raising a Series A financing round that have a board of directors, percentage whose board of directors is controlled by $\mathrm{VC}$ directors (i.e., VC directors have over $50 \%$ of the board seats). Source: Ewens and Malenko (2021). 33. Median age at the time of the IPO of VC-backed startups. Age is defined as the number of years from the startup's first VC financing to the IPO date. Source: VentureSource. 34. Median amount of (primary) capital raised prior to the IPO by VC-backed startups. Source: VentureSource. 